\title{
Analysis Strategy for Small and Medium Business Development Policy Gresik District in East Java
}

\author{
Dr. Rahayu Puji Suci. MS. \\ Management Department, Economic Faculty, University Widyagama Malang, East Java of Indonesia.
}

\begin{abstract}
The objectives of this research study is the preparation of Policy Development Small and Medium Enterprises (SMEs) Gresik regency, East Java. The expected outcome of this activity is the completion of SME Development Policy Gresik regency, East Java. This research included in this type of survey research (survey research). To identify and determine the priority of a number of SMEs are included in the classification of SMEs seed using Location Quotient (LQ). To identify aspects of strategic management of internal and external environmental factors using a matrix of external strategy (External Strategic Factors Analysis Summary / EFAS) and internal strategy matrix factor (Internal Strategic Factors Analysis Summary / IFAS). To analyze the position of SME business unit using the analysis-Market Growth Matrix (BCG's Growth-Share Matrix) and the Industry Life Cycle Matrix analysis (ADL Matrix) to eliminate the weaknesses that exist in the analysis-Market Growth Matrix. Furthermore, the synthesis of the above calculation is used to determine policy formulation and development of SMEs. So from a strategic management analysis results show the development of small and medium enterprises in Gresik is located in Quadrant I, or should do or Aggressive Growth Strategy supports an aggressive growth policy (growth oriented strategy).
\end{abstract}

Keywords: strategy, policy development, SME.

\section{Introduction}

During the past 3 years, Gresik regency economy slowly improved. Economic growth in 2003 amounted to $4.41 \%$ and increased to $6.91 \%$ in 2005 . When compared with 2004 , the growth is faster by a margin of $1.45 \%$, and when compared to growth in 2003 there were difference of $1.05 \%$ growth rate. These conditions clearly indicate a trend of improvement in the economy especially inflation at the same idea also tended to decrease. These conditions suggest that the economy Gresik city moving towards a situation as it was before the 1997 financial crisis in which economic growth Gresik regency had reached 13\%. During this time, the industrial sector dominates economic structure by over $45 \%$ so it determines a good or bad area. If the industrial sector collapsed, the other sectors will be affected, and vice versa if the industry improves, the other sectors will also experience growth.

Conditions of SMEs in Gresik regency has diverse characteristics. This diversity can be seen from the number and types of small and medium industries located in the small, medium and large average recorded a significant increase in the last 5-year period. During this period, small scale industries small increase over 1000 units.

Suwarsono (1994: 22) [1] said that the analysis of the external environment should not be until fall to try to analyze as many variables as possible. Therefore, the external environment will only cover variable variable analyzed government, competitors, and suppliers. In addition to the analysis of external environmental factors, companies also need to conduct an analysis of the internal environment

Based on the phenomenon of SME business Gresik has been said, the research studies with outcomes such as SME development policy Gresik regency, East Java province would be sufficient to immediately formulated strategic. Formulation and determination of SME development policy Gresik is very important in order to be able to release the SMEs of komplektisitas basic problems associated with the realization of business development. On the other hand, research studies focusing on the formulation and development of policyintensive SMEs so far have not worked, so the results of the discussion to solve these problems, and the development of policy implications that need to be implemented has not been developed (Day, George S., 1990) [2], .

For that it is important to analyze the environment will inevitably affect the business's bags and luggage. According to Pearce and Robinson $(2007,84)$ [3], A host of external factors influence a form's choice of direction and action and, ultimately, its organizational structure and internal processes. These factors, wich extend constitute the environment, can be dividend in to three interrelated Subcategories: factors in the remote environment, factors in the industry environment and factors in the operating environment. The remote environment comprices factors that originate beyond. , And Usually irrespective of, any single firm's operating situation: (1) economic, (2) social, (3) political, (4) technological, and (5) ecological factors (Erez, M. and F. Kanfer, 1983) [4],. 
Further Pierce Robinson (2007, 92) [3] defines environment as the general industry conditions for competition that influence all business that provide products and services Similar. The operating environment also called the competitive or task environment, comprises factors in the competitive situation that Affect a firms success in acquiry needed resourches or profitability in marketing its goods and service. Among the most important of these factors are the firm's competitive position, the composition of its costumers, its reputation among suppliers of its, and its ability to attract capable employers (Pearce and Robinson, 2007, 106) [3].

The aim of this activity is the preparation of Policy Development Small and Medium Enterprises (SMEs) Gresik regency, East Java. The expected outcome of this activity is the completion of SME Development Policy Gresik regency, East Java.

According to Idrus (1997, 18-19) [5] planner (strategist) should also be able to measure the strategic advantage (SA)-organizations of the strengths and weaknesses and SBUnya portfolio. SA can be used as a 'Flagship' of the organization compared to rivals. Furthermore Idrus said the strategic plan, should be able to take into account changes in the external environment that provides 'opportunities-opportunities' and 'threatstreat' in the organization.

\section{Methods}

This research study included in this type of survey research (survey research) and use the questionnaire as a data collection tool that subject in the field (Singarimbun and Effendi, 1995:5). [6]

To identify and determine the priority of a number of SMEs are included in the classification of SMEs featured in Gresik using the Location Quotient (LQ). To identify aspects of strategic management of internal and external environment into force (strength), weakness (Weakness), opportunities (opportunity) and threats (threat) for the development of SMEs using the matrix factors external strategy (External Strategic Factors Analysis Summary / EFAS) and matrix factors internal strategies (Strategic Internal Factors Analysis Summary I IFAS).

To analyze the position of SME business unit using the analysis-Market Growth Matrix (BCG'S Growth-Share Matrix) and the Industry Life Cycle Matrix analysis (ADL Matrix) to eliminate the weaknesses that exist in the analysis-Market Growth Matrix. Furthermore, the synthesis of the above calculation is used to formulate and determine policy SME Gresik regency, East Java.

By using strategic factors external and internal, as described in the EFAS and IFAS above, then transfer opportunities and threats from EFAS and add the strengths and weaknesses of the IFAS into the appropriate cell in the SWOT matrix (Figure 2). Based on this approach, it can be formulated an alternative strategy, that strategy SO, ST, WO, and WT.

\begin{tabular}{|c|c|c|}
\hline IFAS & $\begin{array}{c}\text { STRENGTH (S) } \\
\text { 5-10 Determine the internal } \\
\text { power factor }\end{array}$ & $\begin{array}{c}\text { Weakness (W) } \\
\text { 5-10 Determining factors } \\
\text { internal weaknesses }\end{array}$ \\
\hline $\begin{array}{c}\text { OPPORTUNITY (O) } \\
\text { 5-10 Determining factors of } \\
\text { external opportunities }\end{array}$ & $\begin{array}{c}\text { SO STRATEGY } \\
\text { Creating strategies to use force } \\
\text { to take advantage of } \\
\text { opportunities }\end{array}$ & $\begin{array}{c}\text { STRATEGIES WO } \\
\text { Creating strategies that } \\
\text { minimize your weaknesses to } \\
\text { capitalize on opportunities }\end{array}$ \\
\hline $\begin{array}{c}\text { Threat (T) } \\
\text { 5-10 Determining factors } \\
\text { external threats }\end{array}$ & $\begin{array}{c}\text { ST STRATEGY } \\
\text { Create a strategy to address the } \\
\text { threat to use force }\end{array}$ & $\begin{array}{c}\text { STREGIES WT } \\
\text { minimize weaknesses and } \\
\text { overcome threats }\end{array}$ \\
\hline
\end{tabular}

Figure 2. SWOT Matrix Diagrams

Analysis-Market Growth Matrix (BCG's Growth-Share Matrix) is based on the use of Market Growth Rate (Market Growth Rate) and Market Share Relative (Relative Market Share). The market growth rate presented by the vertical axis, while the Relative Market Share represented by the horizontal axis (Figure 3).

The market growth rate can be calculated by the formula:

Industry Sales Volume - Volume Industrial Sales

$$
\text { Year N Year N - } 1
$$

Market Growth Rate =

Industry Sales Volume Year N - 1

Relative market share can be calculated by the formula: Industry Sales Volume Year N 
Relative Market Share =

Main Competitors Sales Volume Year N

X $100 \%$

The four cells in $B C G^{\prime}$ s Growth-Share Matrix provide a clearer picture of the level of market growth rate and relative market share.

High Low

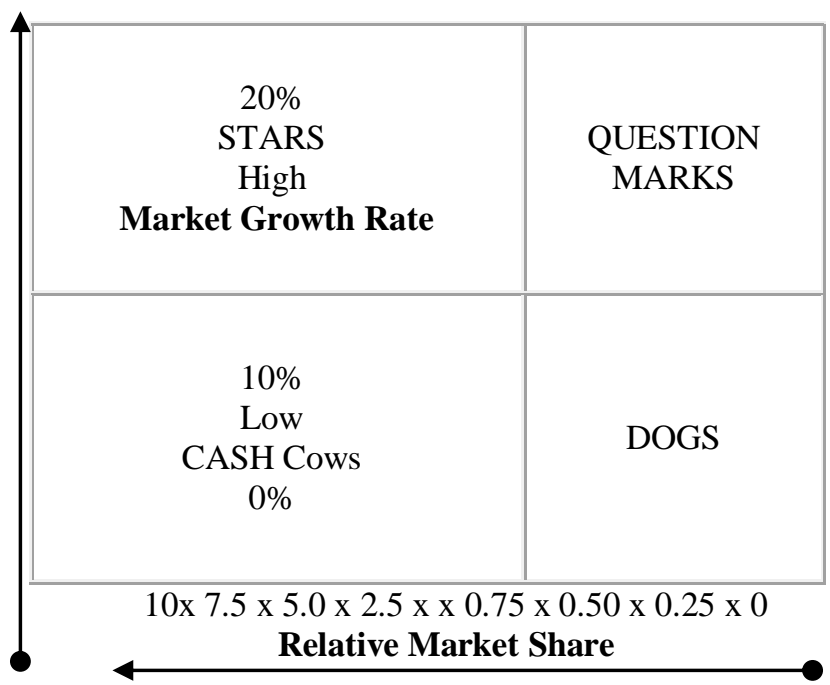

Figure 3.Matrik-Market Growth (BCG's Growth-Share Matrix)

Industry Life Cycle Analysis Matrix (ADL Matrix) is used to eliminate the weaknesses that exist in the analysisMarket Growth Matrix (BCG's Growth-Share Matrix). ADL Matrix has two axes, the vertical axis represents the internal variables (indicated by market share and the company's position relative to its main competitors compared). The vertical axis is divided into six groups with the dominant category, strong, good, last, weak and unknown.

The horizontal axis represents the external variables (indicated by product evolution in the Industry Life Cycle). The horizontal axis is divided into four sections with categories of introduction, growth, maturity, and decline. ADL Matrix can be seen in Figure 4 below.

\begin{tabular}{|c|c|c|c|c|c|}
\hline & \multicolumn{4}{|c|}{ INDUSTRY LIFE CYCLE } \\
\hline & & INTRODUCTION & GROWTH & Maturity & DECREASE \\
\hline \multirow{6}{*}{$\begin{array}{c}\text { POSITION } \\
\text { COMPETITION }\end{array}$} & DOMINANT & $=$ & $=$ & $=$ & $=$ \\
\hline & STRONG & $=$ & $=$ & $=$ & 5 \\
\hline & GOOD & $=$ & $=$ & 5 & $<$ \\
\hline & SURVIVES & $=$ & 5 & $<$ & $<$ \\
\hline & WEAK & 5 & $<$ & $<$ & $<$ \\
\hline & UNKNOWN & $<$ & $<$ & $<$ & $<$ \\
\hline
\end{tabular}

Figure 4. Industry Life Cycle Matrix (ADL Matrix)

According to John A. Pearce II and Richard B. Robinson in his book Strategic Management: Strategy Formulation and Implementation (1988) [3] , the matrix SWOT analysis diagram can be seen in Figure 5 below.

Figure

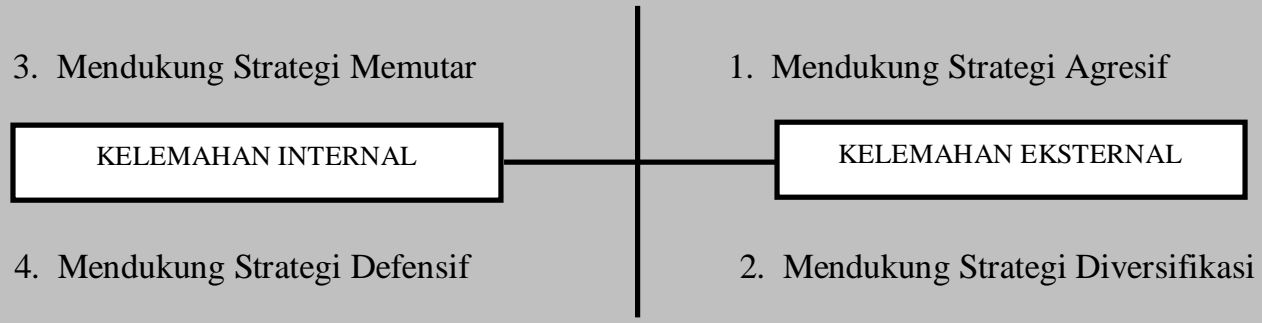




\section{SWOT Analysis Diagram Matrix}

\section{Results And Discussion}

Analysis of the internal environment is a process where planners reviewing marketing strategies and distribution companies, research and development, production and operations, resources and employees as well as finance and accounting factors to which the company has significant capabilities that companies take advantage of opportunities in the most effective and can handle threats in the environment (Jauch and Glueck, 1999:162) [7] . Internal development environmental analysis of small and medium enterprises (SMEs) in Gresik can be broken down as follows:

\begin{tabular}{|c|c|c|}
\hline Internal Factors & List of Strengths and Weaknesses & Ket. \\
\hline \multirow{14}{*}{ Marketing and distribution } & $\begin{array}{l}\text { 1. The creation of a strong market share in the entire } \\
\text { sub-market of marketing or significant }\end{array}$ & 0 \\
\hline & $\begin{array}{l}\text { 2. Market research system is ineffective and } \\
\text { inefficient - the system does not do market research }\end{array}$ & - \\
\hline & $\begin{array}{l}\text { 3. Product mix: the quality of the product is or the } \\
\text { average for the industry }\end{array}$ & 0 \\
\hline & $\begin{array}{l}\text { 4. Product lines: product line and mix incomplete. } \\
\text { Stage of the product life cycle is between growth } \\
\text { stage (Stage I) and stage of development (Phase II), } \\
\text { have not reached the stage of maturity or maturity } \\
\text { (Phase III) }\end{array}$ & - \\
\hline & 5. Leadership of new product low & - \\
\hline & $\begin{array}{l}\text { 6. Patent protection (or the same level of legal } \\
\text { protection for the product) is never done }\end{array}$ & - \\
\hline & $\begin{array}{l}\text { 7. The company has a positive outlook and } \\
\text { satisfactory services to end consumers }\end{array}$ & + \\
\hline & $\begin{array}{l}\text { 8. Product packaging (or equal to the product) is done } \\
\text { efficiently and effectively }\end{array}$ & + \\
\hline & 9. Pricing strategy is implemented effectively & + \\
\hline & $\begin{array}{l}\text { 10. Salespeople have a relationship with potential } \\
\text { customers }\end{array}$ & + \\
\hline & $\begin{array}{l}\text { 11. The Company has a sensitivity in terms of } \\
\text { concentration of sales to some customers }\end{array}$ & + \\
\hline & $\begin{array}{l}\text { 12. The company runs advertising so effectively } \\
\text { managed to create a brand image of a product or } \\
\text { company to be able to develop a loyal customer or } \\
\text { increase customer loyalty }\end{array}$ & + \\
\hline & $\begin{array}{l}\text { 13. Activities outside advertising marketing campaign } \\
\text { is done efficiently and effectively }\end{array}$ & + \\
\hline & $\begin{array}{l}\text { 14. Distribution channels and geographical coverage } \\
\text { is average for the size of the industry, including } \\
\text { efforts in the enterprise }\end{array}$ & 0 \\
\hline \multirow{6}{*}{$\begin{array}{l}\text { Research \& Development and } \\
\text { Engineering }\end{array}$} & $\begin{array}{l}\text { 15. Fundamental research in relation to the creation } \\
\text { of new or improved product to be marketed is never } \\
\text { done }\end{array}$ & - \\
\hline & $\begin{array}{l}\text { 16. Applied research and research development in } \\
\text { relation to the creation of new or improved products } \\
\text { to the market as well as for engineered products to } \\
\text { industrial size less sustainable }\end{array}$ & 0 \\
\hline & $\begin{array}{l}\text { 17. Product design and design and improvement } \\
\text { processing is quite good }\end{array}$ & + \\
\hline & 18. Development of a high packing being created & 0 \\
\hline & $\begin{array}{l}\text { 19. The ability to meet the design goals and desires of } \\
\text { consumers is quite satisfactory }\end{array}$ & + \\
\hline & 20. Laboratory and product testing facilities is & 0 \\
\hline
\end{tabular}




\begin{tabular}{|c|c|c|}
\hline & incomplete and inadequate & \\
\hline & $\begin{array}{l}\text { 21. Technicians and experts who are trained and } \\
\text { experienced quite adequate for the size of the industry }\end{array}$ & + \\
\hline & $\begin{array}{l}\text { 22. Inadequate working environment / fit for } \\
\text { creativity and invention of new products }\end{array}$ & - \\
\hline & $\begin{array}{l}\text { 23. The manager can explain the target to researchers } \\
\text { and research results to higher manajeer }\end{array}$ & + \\
\hline & $\begin{array}{l}\text { 24. Management companies are less able (for the size } \\
\text { of the industry) to carry out an effective forecasting } \\
\text { technology }\end{array}$ & - \\
\hline & $\begin{array}{l}25 \text {. Total operating cost on average is lower than the } \\
\text { total cost competitors }\end{array}$ & + \\
\hline & 26. Capacity to meet market demand in accordance & + \\
\hline & $\begin{array}{l}\text { 27. Average facilities are old and outdated for the size } \\
\text { of the industry }\end{array}$ & - \\
\hline & 28. Raw materials and sub-assembly cost control & + \\
\hline Production and Operations & $\begin{array}{l}\text { 29. Availability of raw materials and sub-assembly of } \\
\text { sufficient }\end{array}$ & + \\
\hline Management & $\begin{array}{l}\text { 30. What facilities and offices strategically pretty } \\
\text { average for the size of the industry }\end{array}$ & 0 \\
\hline & 31. Inventory control system is efficient and effective & + \\
\hline & $\begin{array}{l}\text { 32. Average procedure is efficient and effective for } \\
\text { the size of the industry: the design, scheduling, } \\
\text { quality control }\end{array}$ & 0 \\
\hline & $\begin{array}{l}\text { 33. Vertical integration and supplier relationships } \\
\text { effectively carried }\end{array}$ & + \\
\hline & $\begin{array}{l}\text { 34. The size of the company in conjunction with the } \\
\text { industry (barriers to entry) is to measure industry }\end{array}$ & 0 \\
\hline & $\begin{array}{l}\text { 35. The support system is quite effective corporate } \\
\text { staff implemented }\end{array}$ & + \\
\hline & $\begin{array}{l}\text { 36. Work experience and achievements balanced top } \\
\text { management: top managers can work well together as } \\
\text { a team }\end{array}$ & + \\
\hline Resources and Employees & $\begin{array}{l}\text { 37. Policy efficient and effective working } \\
\text { relationship: the appointment of staff, assessment and } \\
\text { promotion of training and development and reward } \\
\text { and benefits }\end{array}$ & + \\
\hline & $\begin{array}{l}\text { 38. The average labor cost low for the size of the } \\
\text { industry (according to the size of the compensation, } \\
\text { reimbursement and absenteeism) }\end{array}$ & - \\
\hline & $\begin{array}{l}\text { 39. Information management and computer systems } \\
\text { are not effective }\end{array}$ & - \\
\hline & 40. Profit consistent but average for industrial size & 0 \\
\hline Finance and Accounting & $\begin{array}{l}\text { 41. Balance Sheet shows the ability to obtain } \\
\text { necessary capital, the equity ratio low-receivables, } \\
\text { working capital position is high and stock prices quite } \\
\text { fun }\end{array}$ & + \\
\hline
\end{tabular}

Note:

1. Sign (+) declared force; signs (0) declared neutral; dash (-) state weakness

2. Strength has a value of (+) 19; weakness has value (-) 10 .

Analysis of the external environment is a strategic planning process that is used to monitor the environmental sector in determining opportunities and threats to the company (Jauch and Glueck, 1999:88). Jauch and Glueck (1999:89) [7] adds that the company's management needs to systematically analyze and diagnose the external environment due to environmental factors is a major influence to change strategy. Analysis of the external environment and middle development of small businesses (SMEs) in Gresik can be broken down as follows:

Ket. 


\begin{tabular}{|c|c|c|}
\hline \multicolumn{3}{|l|}{ General Environment } \\
\hline \multirow{7}{*}{ Socio-economic } & Economic factors: & \\
\hline & $\begin{array}{l}\text { 1. Symptoms of inflation in the prices of goods tend } \\
\text { to be high and the symptoms of deflation in the prices } \\
\text { of goods tend to be low = there should be controls on } \\
\text { wages and prices }\end{array}$ & - \\
\hline & $\begin{array}{l}\text { 2. Financial policy, interest rates, currency } \\
\text { devaluation or revaluation of foreign currencies in } \\
\text { relation to quite conducive }\end{array}$ & + \\
\hline & $\begin{array}{l}\text { 3. Fiscal policy: tax rates for corporations and } \\
\text { individuals on average are not quite conducive }\end{array}$ & 0 \\
\hline & $\begin{array}{l}\text { 4. Balance of payments in connection with foreign } \\
\text { trade is quite conducive }\end{array}$ & + \\
\hline & $\begin{array}{l}\text { 5. Climatic and ecological factors: strategic planners } \\
\text { with insight sufficient climatic and ecological }\end{array}$ & + \\
\hline & $\begin{array}{l}\text { 6. Social factors: strategic planners followed the } \\
\text { changes in the level of education and social values to } \\
\text { assess their impact on the strategy implemented }\end{array}$ & \\
\hline \multirow[t]{2}{*}{ Technology } & $\begin{array}{l}\text { 7. Less effective strategic planners researching the } \\
\text { technology to look for changes that may affect raw } \\
\text { materials, operations, products and services. Changes } \\
\text { in technology can provide great opportunities for } \\
\text { improving outcomes, goals, or otherwise threaten the } \\
\text { company. }\end{array}$ & - \\
\hline & $\begin{array}{l}\text { 8. Technological changes affecting current products } \\
\text { in terms of the production process is never done }\end{array}$ & - \\
\hline \multirow{7}{*}{ Government } & $\begin{array}{l}\text { 9. The government is a major buyer for industrial } \\
\text { products }\end{array}$ & + \\
\hline & $\begin{array}{l}\text { 10. The government provides subsidies to the } \\
\text { company and the industry, which means helping their } \\
\text { survival to be able to continue to grow }\end{array}$ & + \\
\hline & $\begin{array}{l}\text { 11. The government protects domestic producers } \\
\text { against foreign competitors 'unfair' }\end{array}$ & + \\
\hline & $\begin{array}{l}\text { 12. Changes in government policy to increase the } \\
\text { opportunities and the emergence of new business for } \\
\text { the company }\end{array}$ & + \\
\hline & $\begin{array}{l}\text { 13. Anti-monopoly legislation and policies restricting } \\
\text { mergers }\end{array}$ & + \\
\hline & $\begin{array}{l}\text { 14. Government regulations that significantly affect } \\
\text { the strategic choices of the whole industry }\end{array}$ & 0 \\
\hline & $\begin{array}{l}\text { 15. Government policies are changing the economic } \\
\text { conditions that may pose a threat to the company }\end{array}$ & - \\
\hline \multicolumn{3}{|l|}{ Industry Environment } \\
\hline Markets and Consumers & $\begin{array}{l}\text { 16. Size (percent and potential), growth and } \\
\text { siklisalitas (product life cycle), overseas opportunities }\end{array}$ & + \\
\hline Supplier & $\begin{array}{l}\text { 17. Availability of inputs required, the cost of inputs, } \\
\text { power supplier }\end{array}$ & + \\
\hline Competition & $\begin{array}{l}\text { 18. Foreign competitors, the availability and cost of } \\
\text { replacement of other industries }\end{array}$ & - \\
\hline \multirow{2}{*}{ International Environmental } & 19. Opportunities for international activities & + \\
\hline & 20. Threats to international activities & - \\
\hline
\end{tabular}

Note:

1. Sign (+) states opportunities; signs (0) declared neutral; dash (-) state threat

2. Opportunity has a value of (+) 11 ; Threat has a value (-) 6. 
Based on the results of the scoring of the factors internal and external environments above, it can be noted: (1) power value (+) 19, (2) weakness has a value of (-) 10, (3) opportunities have value (+) 11, and (4) the threat value (-) 6.

Based on the results of the scoring of the factors internal and external environments above, it can be argued that the point of intersection of each value strengths, weaknesses, opportunities and threats are located at point $\mathrm{X}$ as shown in Figure 6 below.

\begin{tabular}{|c|c|}
\hline \multicolumn{1}{|c|}{ Opportunity } \\
III & I \\
Playing Strategies & Aggressive Strategy \\
\hline $\begin{array}{c}\text { Weakness Strength } \\
\text { Defensive Strategies } \\
\text { IV }\end{array}$ & Diversification Strategy \\
\hline
\end{tabular}

Threat

Figure 6. SWOT Analysis Diagram Matrix BUSINESS DEVELOPMENT small and medium enterprises (SMEs) in Gresik, East Java Province

Source: Results of Data Analysis Research, 2007; Processed.

From Figure 6 it can be argued that the point X (SWOT matrix analysis charts the development of small and medium enterprises (SMEs) in Gresik, East Java lies in Quadrant I. This means generally small and medium enterprises (SMEs) in Gresik in developing a business are in the most favorable conditions. Small and medium enterprises (SMEs) in Gresik regency has many strengths that can be used to take advantage of opportunities to achieve the goal. At these conditions, small and medium enterprises (SMEs) in Gresik should perform Strategy Aggressive Growth. This is in accordance with the opinion of Jauch and Glueck (1999:286) [7] that the strategy should be applied in this condition is to support aggressive growth policy (growth oriented strategy). Analysis-Market Growth Matrix (BCG's Growth-Share Matrix) is based on the use of Market Growth Rate (Market Growth Rate) and Market Share Relative (Relative Market Share). The market growth rate presented by the vertical axis, while the Relative Market Share represented by the horizontal axis.

The market growth rate can be calculated by the formula:

Industry Sales Volume - Volume Industrial Sales

Market Growth Rate $=\frac{\text { Year N } \quad \text { Year N - 1 }}{\text { Industry Sales Volume Year N - 1 }}$

Relative market share can be calculated by the formula: Industry Sales Volume Year N

Relative Market Share

Main Competitors Sales Volume Year N

Furthermore, the volume of sales of small and medium enterprises (SMEs) from Gresik and sales volume of small and medium enterprises (SMEs) from BAKORWIL III Malang (competitors) can be seen in Table 1. Table 1. Sales Volume of Small and Medium Enterprises (SMEs) from Gresik and BAKORWIL III Malang (Competitor) Year 2004-2006

\begin{tabular}{|c|c|c|c|}
\hline \multirow{2}{*}{ No } & \multirow{2}{*}{ Year } & \multicolumn{2}{|c|}{ Sales Volume of Small and Medium Enterprises (SMEs) (Euro / year) } \\
\cline { 3 - 4 } & & Gresik & BAKORWIL III Malang \\
\hline 1. & 2004 & 283500250 & 648750250 \\
\hline 2. & 2005 & 315 million & 720 million \\
\hline 3. & 2006 & 356500500 & 792250500 \\
\hline
\end{tabular}

Source: Results of Data Analysis Research, 2007; Processed

Based on Table 1, it can be calculated rate of market growth and relative market share, namely:

Market Growth Rate $=$ $356500500-315000000$ $=0.13=13 \%$

315 million

Relative Market section $=$

$\frac{356500500 \times 100 \%}{792250500}$

$$
=45 \%=0.45
$$

Based on the calculation above, the rate of market growth of small and medium enterprises (SMEs) from Gresik is 0.13 or $13 \%$. Market growth rate of $13 \%$ categorized as high, since the measurement is greater than the 
standard market growth rate, ie 10\% (Philip Kotler, 1992:169) [8] . The ratio between the volume of sales of small and medium enterprises (SMEs) from Gresik regency with small and medium enterprises (SMEs) from BAKORWIL III Malang in 2006 was 0.45 . Relative market share of 0.45 considered low, because it is smaller than a standard measurement of the relative market share, which is 1.00 (Philip Kotler, 1992:169) [8] . Furthermore, analysis of the matrix diagram Growth-Market Parts of Boston Consulting Group; BCG (BCG's Growth-Share Matrix) small and medium enterprises (SMEs) in Gresik can be seen in Figure 7 below.

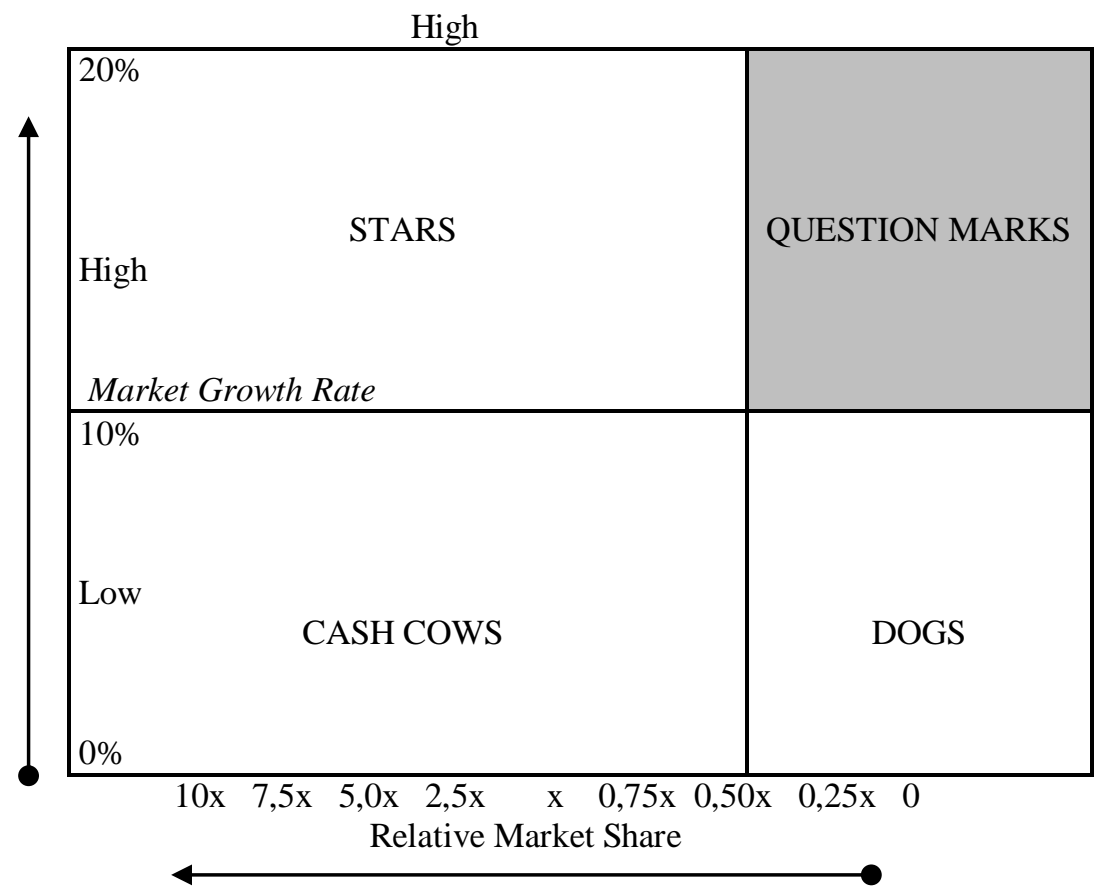

Low

Figure 7. Growth-Market Matrix (BCG's Growth-Share Matrix) ukm Kabupaten Gresik Source: Results of Data Analysis Research, 2007; Processed

\section{Conclusion}

1. Based on the results of the scoring of the internal and external environment that influence the development of small and medium enterprises (SMEs) in Gresik which then formulated the matrix SWOT analysis diagram, the strategic management of small and medium enterprise development in Gresik is located in Quadrant I, or Aggressive Growth Strategy should perform or support an aggressive policy of growth (growth oriented strategy).

2. Based on the results of the calculation of the growth rate of the market and the market is relatively businesses of small and medium enterprises (SMEs) in Gresik which then formulated on the diagram analysis matrix Growth-The Market of the Boston Consulting Group; BCG (BCG's Growth-Share Matrix), the industrial enterprises small and medium enterprises in Gresik in the position of Question Marks, or in other words, small businesses and medium-sized industrial enterprises in Gresik regency has a chance to grow and develop, but needed cash flow (cash flow) are sufficient in order to increase their relative market share.

3. Based on the results of the analysis of strategic management aspects of the external and internal environment is formulated in matrix SWOT analysis diagram, calculating the market growth rate and relative market share is formulated in matrix analysis diagram Growth - The Market of the Boston Consulting Group; BCG, and confundamental consideration in order to determine the strategy, the strategic management model is offered for the development of small and medium industrial enterprises in Gresik is doing Aggressive Growth Strategy to Increase Market Section Relative (Relative Market Share).

4. Based on the results of the analysis of aspects of strategic management of the external and internal environment is formulated in the diagram analysis matrix, SWOT, calculation of market growth and market share relative is formulated in the diagram analysis matrix Growth - The Market of the Boston Consulting Group; BCG (BCG's Growth-Share Matrix), and basic considerations for establishing the strategy, the strategic management model is offered for the development of small and medium industrial enterprises in Gresik are doing Strategy Playing with Improved Growth Market (Market Growth Rate) and The Market Relative (Relative Market Share ).

\section{Recommendation}


1. In an effort to increase market share relative, while maintaining its aggressive growth strategy, the small and medium industrial enterprises in Gresik advised to apply and develop the following strategies:

a. Generic Strategies, by one and / or more of the following strategies:

(1) Increase market opportunities by producing the same cost as the main competitor or back regularly and get in on a niche market that is not entered into the main competition.

(2) Build market share with lower prices (cost leadership), or differentiation strategy on quality, technology, service, and innovation.

b. Focused strategy, by doing one and / or more strategies that focus on something different, as follows:

(1) Strategy to fill a gap - entered the market and focus on a narrow slit or the final consumer is ignored by major competitors or market leader.

(2) Strategy specialist, specializing to establish the relative market share and competitive advantage through specific capabilities to meet specific market segment, buyers with special needs.

(3) strategies targeting the premium market on the basis of which focus on product differentiation fancy or unique.

(4) The strategy that looks different, that take different positions with major competitors or market leader.

(5) acquisition strategy, ie joining or buying weaker competitors to form a new company that had a market share larger or stronger competitive advantage.

2. In an effort to increase the rate of market growth and market share relative to support its aggressive growth strategy, the small and medium industrial enterprises in Gresik also advised to development strategies as follows:

a. Revise the old strategy: (1) to make changes to the approach of the new competition to rebuild the market growth rate and relative market share, (2) improving internal operational activities and strategic to provide better support to the company's overall strategy, (3) merger with another company to form synergies, (4) withdraw or reduce activity not in accordance with the company's core business.

b. Make efforts to boost sales - lower prices, increase promotion, increase customer service, and improve the performance of the product as soon as possible.

c. Encourage reduction in costs through cost structure and flexibility of the company's value chain, including the cost savings in general.

d. Selling assets that do not need to raise cash and save the effort.

e. Consider supplements steps as follows: (1) (assumed to still have the financial resources) to run an offensive strategy based rotating low cost and differentiation, (2) maintain the offensive its market share, sales levels, and competitive position at current levels and (3) Harv est strategy - trying to keep costs to a minimum outlay of cash and trying to survive while out of the market as soon as possible on a regular basis.

\section{References}

[1] Suwarsono, 1994. Strategic Management: Concepts and Context Analysis Tool, Academy of Management Company UPP YKPN, Yogyakarta.

[2] Day, George S., 1990, Market Driven Strategy. New York: The Free Press.

[3] Pearce and Robinson, 2007, Strategic Management formulation, emplementation, and control. Mc Graw Hill, Company Inc. New York.

[4] Erez, M. and F. Kanfer, 1983, "The Role of Goal Acceptance in Goal Setting and Task Performance", Academy of Management Journal 8, no.3 (Juli): 457.

[5] Idrus, M.S. 1997. Strategi : Sebagai Upaya Untuk Meningkatkan Kinerja Organisasi dan Keunggulan Bersaing, Universitas Brawijaya, Malang.

[6] Singarimbun, Masri dan Sofian Effendi, 1995, Metode Penelitian Survai, PT. Pustaka LP3ES Indonesia, Jakarta.

[7] Jauch, R. Lawrence and William F. Glueck, 1988, Strategic Management and Business Policy, McGraw-Hill, Inc.

[8] Philip kotler, 1992, Manajemen pemasaran (terjemahan), Prenhallindo, Jakarta. 